\title{
TEACHERS' SPEECH TO STIMULATE STUDENTS IN LEARNING INTERACTION
}

\author{
Imam Suyitno $^{1}$, Martutik ${ }^{1}$, Wevi Lutfitasari ${ }^{1}$, Heni Dwi Arista ${ }^{2}$ \\ ${ }^{1}$ Universitas Negeri Malang (UM) dan ${ }^{2}$ Universitas Brawijaya Malang (UB), Malang, Indonesia \\ Jalan Semarang 5, Malang 65145, Indonesia \\ Corresponding Author: imam.suyitno@fs.um.ac.id
}

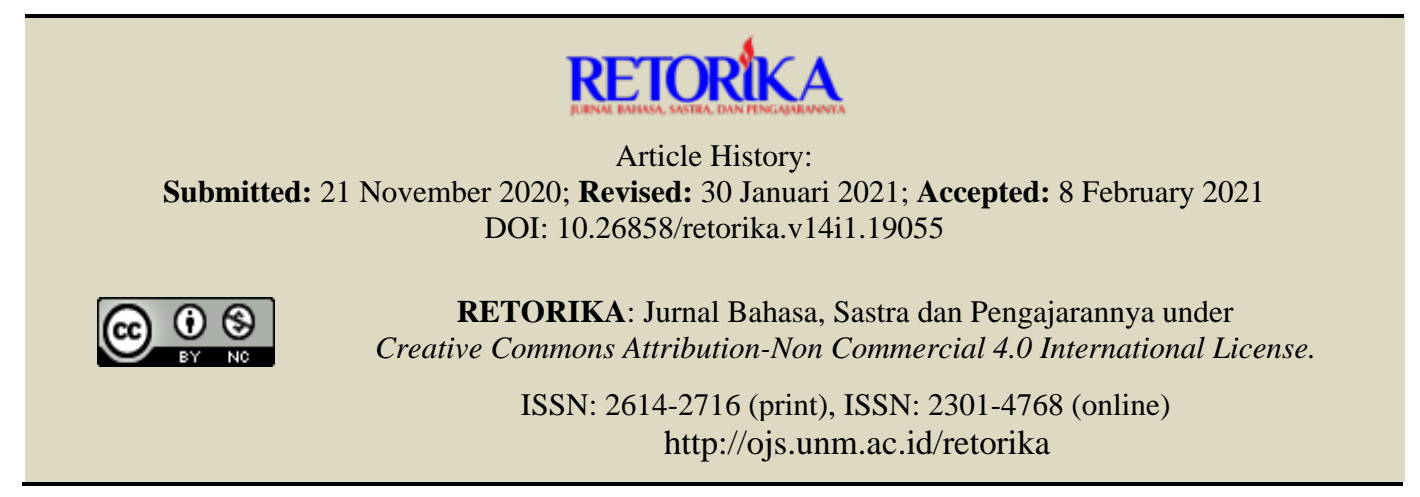

\begin{abstract}
Many learning theories and studies on classroom discourse explain that teachers' speech has an important role in determining student learning success. The teachers' speech in teachinglearning interactions influences the activity and comfort of students' learning. This study aimed to describe how the teachers' speech to stimulate students in learning inteaction. This study used a qualitative approach to the type of classroom research. Participants in this study were 4 teachers who taught Indonesian, Mathematics, Science, and English at Mts. Islamiyah. Data of the study were the teachers' speech and its context of stimulating students in learning interaction. The data collected through classroom observations and recording of teachers' speech and the context of the speech. By qualitative analysis, this study found that the teachers' speech at the beginning of learning, in the learning process, and at the end of learning has various types and functions depending on the speech context underlying the speech events in the classroom interaction. The speech context includes students as audiences, speech functions, learning material as speech topics, learning interactions as speech situations. The use of teachers' speech was a learning strategy conducted by teachers to stimulate students motivated for learning.
\end{abstract}

Keywords: Teachers' Speech, Stimulate Students, Students' Enthuciasm, Learning Interaction

Teacher plays an important role in the implementation of teaching and learning activities. In teaching and learning interactions, the teacher acts as a motor, facilitator, organizer, motivator, and catalysator for students who have a big contribution in determining the smooth communication in achieving learning goals. Teachers who can develop good communication in interactions with students will be able to improve the quality of learning processes and outcomes. Fraser (2012) said that teacher who have reliable attitudes and abilities have a significant impact on learning. Teacher is not only the driving force of learning, but they are educated figures who are passionate, emotionally intelligent, creative, and ready to face challenges. 
Such teacher potential can support developing good relationships with students and helping them improve their learning skills (Buzzelli \& Johnston, 2014).

Good teacher behavior will appear in high attitudes and willingness to improve the learning situation. They always speak and act lovingly to develop their students' enthusiasm and learning experience. When facing such a teacher, students feel that they get an exemplary figure who can support them in overcoming difficulties and assisting them in obtaining the expected learning experience (Cao, 2011). A good relationship between a teacher and students is very useful in creating a classroom environment that has a good social-emotional climate. Such class interaction will make students emotionally aware of being actively involved in learning.

Learning interaction is a two-way relationship that involves the activity of teachers and students for the achievement of learning goals. The choice of speech as a vehicle of communication becomes the main aspect that must be considered by the teacher in learning interactions. Teachers' speech that is relevant to students' learning needs will stimulate students to be enthusiastic in learning. This is in line with research conducted by Yusuf \& Novita (2020) whose results showed that the effectiveness of the process and learning outcomes have a close relationship with the proficiency of teachers in language. Teacher skills in languages have a positive relationship with the ability to manage classrooms and communicate lesson content. The relevance of the teachers' speech to students' need can be understood from the speech type, speech features, and speech meanings. The teachers' speech will contribute significantly to students if the three aspects can stimulate students' enthusiasm. That way, the teachers' speech conveys educational values stimulating students eager to learn and foster them actively involved in gaining learning experiences.

In the context of learning interactions, the teacher's of speech correlates with understanding communication. This understanding is said by 'Mercer (as quoted by Sharpe, 2008) as' principled understanding', ie students can understand the procedures, processes, conclusions of the communication. This understanding arises because dialogically there is a match between the teachers' speech style and students' abilities. In class interaction, understanding the principle can be built through the selection of speech styles for learning communication. Also, partnerships between teachers and students in good interactions through the provision of information, guidance, and support can create student understanding in learning activities (Wells, 1999).

Teacher's speech has an important role in stimulating student enthusiasm so that the learning process can take place effectively. Research conducted by Wicaksono (2016) showed that in teaching speaking, teacher speech that is understood by students can enrich student vocabulary and encourage students to feel comfortable in learning. Another study of teacher speech was conducted by Andewi \& Waziana (2019) whose results showed that in learning, teachers used more directive speech to manage and control student behavior in the teachinglearning process. The research findings confirmed that teacher speech is an important factor in improving the quality of the process and controlling student enthusiasm for learning to achieve learning outcomes effectively. Nasir et al. (2019) also conducted research on teacher speech in learning for EFL students whose results showed that to direct and control students in learning, teachers use various forms and functions of speech. For this reason, this study attempted to describe how the teacher's speech can stimulate students in the teaching-learning process.

This study aimed to describe the teachers' speech to stimulate students' enthuciasm in classroom interaction. The teachers' speech in stimulating students' readiness for learning certainly different from the teachers' speech in stimulating students' concentration in learning process and students' enthusiasm at the end of learning. Based on this objective, the study sought answers to the question "how is the teachers' speech to stimulate students' enthuciasm in classroom interactions?" In detail, the study sought answers to the questions below.

(a) How is the teacher's speech to stimulate students at the beginning of the learning process?

(b) How is the teacher's speech to stimulate students to be always enthusiastic during the learning process? 
(c) How is the teacher's speech to stimulate students to maintain learning enthusiasm at the end of the learning process?

The findings of this study provide a meaningful contribution for teachers in carrying out teaching assignments. These findings can be a reference in choosing the right variety of speech and speech styles to stimulate student in learning. For further researchers, these findings can be a source of reference in developing the theoretical framework, research design, and discussion of the results of their studies.

\section{METHOD}

This study used a qualitative approach to the type of classroom research. The study analyzed the teacher's speech in classroom interactions conducted at MTs Islamiyah Songgon, Songgon District, Banyuwangi Regency, East Java, Indonesia. The choice of location was based on the consideration that the school is a marginal school with low student motivation. In such conditions, the teacher played an important role in stimulating students to be prepared and concentrate on learning.

This study examined the teacher's speech in the interaction of learning Indonesian, mathematics, science, and English so that this study involved 4 teachers as participants. The selection of the subjects was based on the consideration that (1) the use of four different subjects was intended to avoid speech bias caused by the content of the learning experience being taught, and (2) the four subjects were compulsory subjects, and (3) those subjects included subjects for national examinations. Meanwhile, in the selection of teachers who were targeted for the study, based on considerations (1) the teachers were permanent teachers in the school, (2) the teachers were senior teachers who had a lot of experience in teaching the lessons, (3) the teacher was a favorite teacher for students, (4) the teachers were willing to be observed, and (5) the teachers gave permission to record their speech.

The data were the speech of the teacher in the context of stimulating students to be ready and active in learning. Therefore, the data used in this study were verbal data in the form of a teacher's speech and the context of the use of the speech. The data were collected through classroom observations and recording of teacher speech along with the context of the speech. The class observations were carried out 2 times for each subject. Teacher speech recording used a hidden electronic recording device so that it did not affect the natural speech of the teacher in interacting. Meanwhile, recording the speech context was done in writing in the observation sheet. Data collection procedures were carried out with the following steps.

(a) The research team conducted a preliminary study by visiting the school that was the location of the study.

(b) Researchers asked for permission from the principal to conduct research and meet with the teacher who is the subject of research to determine the observation schedule.

(c) In accordance with the schedule, the researcher joined the class for orientation and establishes a close relationship with class conditions, without taking notes.

(d) In the next schedule, researchers began recording data by the following learning from beginning to end, without interfering in the process of classroom interaction.

(e) During data recording, the researcher recorded the context of the speech as data that supports the interpretation of the speech.

(f) After observing the second learning schedule, the researcher immediately transcribed the utterances from the recording.

(g) Researchers juxtaposed and associated between utterances that have been transcribed with speech context notes to determine data in accordance with the focus of the study.

(h) The researcher moved the speech and its context into the corpus.

(i) Researchers have obtained data in accordance with the focus being studied.

Data from the recorded teacher's speech and narrative context notes were analyzed through five stages, namely identifying data, classifying data, categorizing data, interpreting findings, and drawing conclusions. Data collected in the corpus were identified through a process of selection and reduction to determine the appropriate data following the focus of the study. Selected data were coded and grouped into three research focuses, namely (a) the teacher's speech to stimulate students at the beginning of learning process, (b) the teacher's speech to stimulate students during the learning process, and (c) the teacher's speech to stimulate students at the end of the learning process. Classified data is 
categorized in units that have the same type, feature, and meaning. Each unit was further interpreted meaning based on theoretical constructs to obtain the findings of the study. Conclusions were drawn based on the results of interpretation by reviewing the data that has been studied and the theoretical framework used.

\section{FINDINGS AND DISCUSSION}

\section{Findings}

\section{Teachers' Speech to Stimulate Students to be Ready at the Beginning of Learning}

At the beginning of learning, teachers used varieties of speech to stimulate students to be ready for learning. When starting a lesson, the teacher greeted and addressed students with the aim of opening communication with students in classroom interactions. The speech can be seen in quotation 1.

\section{Quotation 1: \\ Teacher: Assalamu alaikum .... Good morning .... \\ Teacher: "Hello boy ... are you ok?" \\ Teacher: "Are you oke?"}

(Context: The teacher's utterance was spoken at the beginning of the learning which at the time, the students seemed not ready to learn)

The teacher used greetings in Arabic language. This greeting is a tradition of Islamic schools that must be done by teacher at the beginning of learning. The greeting was followed by greetings in English because the teacher teaches English. Due to no students' response, the teacher addressed them by asking their condition. The use of greetings by the addressing was intended by teacher to attract students' attention.

In attracting students' attention, the teacher begins his communication by making small talk with the topic about class conditions. The speech can be exemplified in quotation 2 .

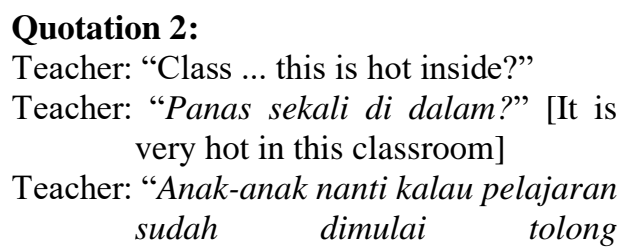

didengarkan!" [When the lesson begin, you have to listen please]

(Context: The speech was spoken by the teacher because the class situation was crowded and the temperature in the class was quite hot)

The teacher opens class interaction by making small talk about the condition of the class. The speech was uttered by the teacher in English followed by translation in Indonesian. The use of the small talks was intended to attract students' attention. Because the classroom atmosphere is not conducive, the teacher asks students to be more focused on the lesson. The speech was spoken by the teacher in a high tone and in the form of a request because with small talk, the atmosphere of the class was still not conducive.

To direct attention to start the lesson, the teacher asks the assignment or work given in the previous lesson. The speech of asking about the past lessons and assignments can be seen in the quotation 3.

\author{
Quotation 3: \\ Teacher: "Ada PR?" [any homework?] \\ Teacher: "What is it?" \\ Teacher: "Apa itu?" [what is it] \\ Teacher: "About?" \\ Teacher: "Tentang?" [about]
}

(Context: The speech was spoken by the teacher in English and in Indonesian because when asked in English, students did not answer)

The teacher asks about the past lesson and assignment in English and followed by the translation in Indonesia. The speech was used by the teacher to direct students' attention that the lesson will begin.

The teacher's speech asking students for attention can be seen in quotation 4 .

\section{Quotation 4:}

Teacher: "Anak-anak tolong diperhatikan $y a ! "$ [Guys, pay attention please]

Teacher: "Kita akan melanjutkan ke bab berapa?" [What chapter do we will continue?]

Teacher: "Sebelumnya bab berapa?" [What chapter before?]

(Context: When the teacher is already in the classroom, students are still busy with their own business) 
The teacher warned students to prepare themselves for learning. The warning was followed by questions which forced them to recall previous learning experiences. The speech is used by teachers with the intention of forcing students to be better prepared to learn.

The teacher's speech asking previous experiences can be read in quotation 5 .

\section{Quotation 5: \\ Teacher: "Hari ini, kita akan belajar tentang lingkaran" [Today, we will study material about circle] \\ Teacher: "Kalian masih ingat rumus keliling lingkaran?" [Do you remember the formula of around the circle]}

(Context: The teacher explains the learning activities that will be carried out and gives apperception)

The teacher provided information related to the learning activities to be carried out. To begin the lesson, the teacher asks the student's learning experience in the previous lesson. The speech style is used by teachers to prepare students to focus more on the learning process that will be done.

The teacher's speech to give suggestions accompanied by reprimand can be seen in the quotation 6.

Quotation 6:

Teacher: "Tujuan kalian di sini itu belajar, jangan hanya guyonan". [Your goal here is to learn, not just joke]

Teacher: "Ben gak isin ketika ditanya anak $S D$." [So it's not ashamed if asked by elementary school students]

(Context: The speech was spoken by the teacher because he saw students who joked and paid less attention to the lesson)

In starting the lesson, the teacher gave advice to students. The advice was followed by statement of reprimand. The speech aimed to arouse students' enthusiasm for learning.

The teacher's remarks in reminding students of their responsibilities can be seen in the following quotation.

\section{Quotation 7:}

\section{Teacher: "April sudah mulai ujian-ujian, persiapan kalian bagaimana?" [April has started the exams, how are you preparing?] \\ Teacher: "Saya minta kalian benar-benar memanfaatkan waktu tiga bulan ini!" [I ask that you take advantage of these three months]}

(Context: the speech was delivered by the teacher in relation to the national examination)

The teacher reminds students to care in learning because they will face the task for which they are responsible. Also, the teacher checks the readiness of students in dealing with these tasks and advises them to make the best use of their time. The speech style is intended by the teacher to arouse student enthusiasm for learning.

\section{Teachers' Speech to Stimulate Students' Enthusiastic During the Learning Process}

During the learning activities, especially during the interaction of the delivery of the core learning material, the teacher always used utterances to stimulate students to be active and enthusiastic in participating in learning. The teachers' speech can be seen in the following quotaton.

In learning interaction, the teacher in stimulating students' enthusiasm to be actively involved in learning used questions followed by reprimands. The speech style can be seen in the quotation 8.

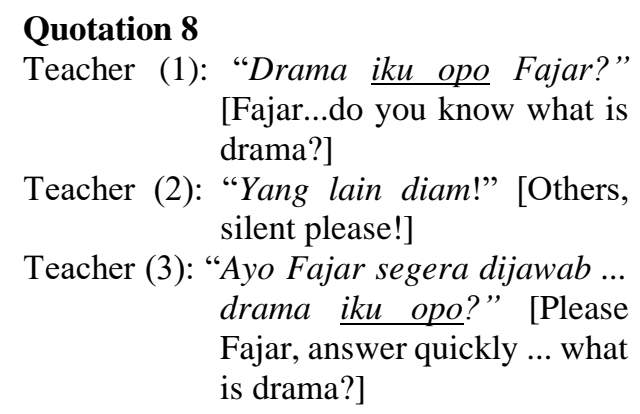

The teacher used speech style in the question feature, namely Drama iku opo Fajar? [Fajar...do you know what is drama?]. The question asked about the learning material that has been studied before. In this case, the teacher performed an apperception process so that students concentrate. In the speech (2), the teacher said Yang lain diam! [Others, silent 
please!]. The speech style includes the warning speech feature used by the teacher to remind other students who are noisy when learning begins. Meanwhile, In the speech (3), the speech style used the teacher is the question feature by request ayo 'please', namely the teacher invites students to be enthusiastic in answering questions raised by the teacher.

The teacher's style of speech in the form of giving questions followed by instructions can be seen in quotation 9 .

\section{Quotation 9: \\ Teacher (1): "Novi teks tanggapan itu apa?" [Novi, what is the response text] \\ Teacher (2): "Kalau tanggapan itu kometar... teks tanggapan itu apa?" [If the response comments... so what is the response text] \\ Teacher (3): "He ...itu ada di buku!" [Hay ... it is you can see in the book]}

The teacher used the speech style of a question feature guided by explanation. It can be seen in the speech that "Kalau tanggapan itu kometar... teks tanggapan itu apa?" [If the response comments... so what is the response text]. The speech style to ask about the material being discussed. The question is conveyed by the teacher to arouse students eager to learn when students' attention to learning interactions begins to diminish. In the speech (3), the teacher said "He ...itu ada di buku!" [Hay ... it is you can see in the book]. Through the speech, the teacher acts to inform students about the learning material that is being learned. Therefore, the speech has the meaning of giving information.

In learning English, the teacher stimulates students' enthusiasm to be actively involved in learning. The speech style used by the teacher in English learning interactions is exemplified in quotation 10.

\footnotetext{
Quotation 10:

Teacher (1): "Dewi, are you oke?"

Teacher (2): "What happens with Dewi?"

Teacher (3): "Because of the last meeting ... about recount text..."

Teacher (4): "Nah, sebenarnya saya ingin sekali Dewi bercerita, sebab apa yang terjadi dengan Dewi sebenarnya cocok sekali loh
}

\begin{abstract}
dengan pembelajaran ini." ["Well, actually I want Dewi to tell me because what happened to Dewi fits perfectly with this learning]
\end{abstract}

In the interaction of English learning, the teacher explains the topic of an interesting experience. In that class, some students have an experience that fits the topic. However, these students did not interest the learning process. In the speech (1) and (2), the teacher said "Dewi, are you oke?" and "What happens with Dewi?" The feature of greeting question used by the teacher to build a sense of closeness between the teacher and students so that student is motivated and eager to learn. In the speech (3), the teacher said: "Nah, sebenarnya saya ingin sekali Dewi bercerita, sebab apa yang terjadi dengan Dewi sebenarnya cocok sekali loh dengan pembelajaran ini." ["Well, actually I want Dewi to tell me because what happened to Dewi fits perfectly with this learning]. It is the speech style by expression feature to build students' confidence related to the content of the learning material. In (1) and (2), the teacher wants to know the condition of students who do not want to answer the teacher's questions. In this context, the teacher takes action asking for information. Meanwhile, in the speech (3), the teacher expressed his/her expectation that the speech has the meaning of hopeful actions.

In learning Math, the teacher stimulates students' enthusiasm to be actively involved in learning. The speech style used by the teacher in the learning Math is exemplified below.

\section{Quotation 11:}

Teacher (1): "Mas, pisang goreng harganya lima ratus rupiah belinya lima ribu, dapat berapa?" [Brother, a fried banana costs five hundred rupiahs ... you buy with five thousand, how many fried bananas do you get?]

Teacher (2): "Sepuluh" [ten]

Teacher(3):"Kok entok sepoloh darimana?" [why do you get ten fried bananas, from which you get it?]

Teacher (4): "Kan sederhana tinggal lima ribu dibagi lima ratus." [It is so simple one that only divides five thousand by five hundred]

Teacher (5): "Semudah itu, tapi karena sampean terbiasa malas 


\section{mikir." [That's very easy, but you are used to lazy thinking] \\ Teacher (6): "Mangkane sampean itu harus paham teori dan rumusnya!" [Therefore, you must understand the theory and formula]}

In the speech (1) -- (4), the teacher explains the learning material used the speech style by a statement feature using a concrete manner with a systematic procedure. In the speech (5), the teacher used the type of statement blaming students who are lazy to learn. In a speech (6), the teacher used the type of suggestion statement to advice students to study hard. In the speech (5), the teacher said "Semudah itu, tapi karena sampean terbiasa malas mikir." [That's very easy, but you are used to lazy thinking] and (6) "Mangkane sampean itu harus paham teori dan rumusnya!" [Therefore, you must understand the theory and formula]. The utterance (5) has the meaning of a mocking, while utterance (6) has the meaning of suggestion. The speech is uttered by the teacher in the interaction of learning mathematics. The teacher feels annoyed because students are not able to work on simple calculation questions.

In the interaction of learning Natural Sciences, the teacher stimulate students' enthusiasm to be actively involved in learning. The speech style used by the teacher in the learning Natural Sciences is exemplified in quotation 12.

Quotation 12:

Teacher (1): "Hati berfungsi sebagai tempat mengubahnya provitamin A menadi vitamin A." [The liver functions as a place to turn provitamin A into vitamin A]

Teacher (2): "Vitamin A didapat dari mana?" [Where does Vitamin A come from?]

Teacher (3): "Ha?" [Hah?]

Teacher (4): "Vitamin A ini didapat dari mana?" [Where does Vitamin A come from?]

Teacher (5): "Ayok wes kelas delapan mosok gak iso?" [You are in the eighth grade is not appropriate if you do not understand?]

The speech was uttered by the teacher in learning Natural Sciences. The teacher explains the topic of learning about vitamins, but many students do not pay attention to the subject matter explained by the teacher. The teacher initially used formal type speech styles. However, because many students do not pay attention to the teacher's explanation, eventually the teacher switched to using non-formal speech styles. In the speech (5), the speech style spoken by the teacher was a speech style with the invitation statement feature followed by ridicule. The speech encouraged students' intention to be more enthusiastic about learning. The speech has the meaning of giving assignments.

In the interaction of learning Natural Sciences, the teacher stimulate students' enthusiasm to be actively involved in learning. The speech style used by the teacher in the learning Natural Sciences is exemplified in quotation 13 .

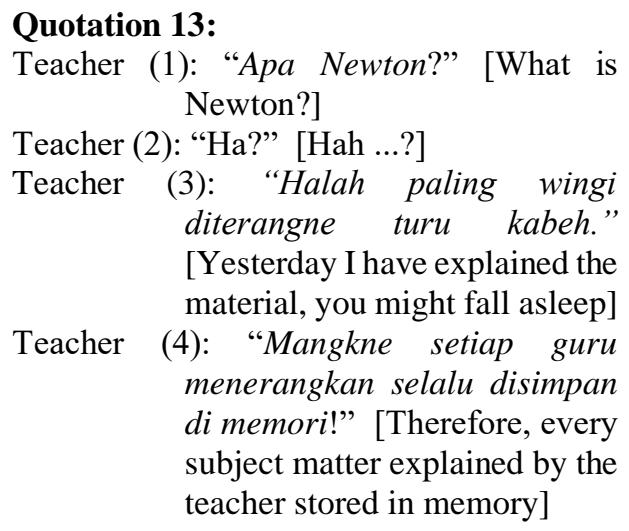

The speech (3) and (4) use non-formal type speech styles. The words used in the speech are the words of regional languages. The sentence is the tone of speech spoken a language in an everyday context. In this interaction, the teacher used the speech style in the form of accusing and bullying expression. It is governing students always actively involved in learning and understanding the subject matter seriously. Viewed from the speech meaning, the speech (3) has the meaning of reprimand, while utterance (4) has the meaning of suggestion.

Teachers' Speech to Stimulate Students to Maintain Their Learning Enthusiasm at the End of the Learning Process

At the end of the learning process, the teacher closes the lesson by reflecting with the aim to maintain student motivation and 
enthusiasm for learning. The teacher stimulates students by using the following utterances.

The teacher reflects on the learning experience and gives suggestions to students. The utterances can be seen in the quotation 14 .

\section{Quotation 14: \\ Teacher: "Bagaimana perasaan kalian dalam belajar tadi?" [How do you feel in studying earlier] \\ Teacher: "Apakah kalian senang?" [Are you happy?] \\ Teacher: "Ayo terus semangat agar lebih bagus lagi." [Let's keep up the good work!]}

The teacher asks students' impressions and experiences in learning. This is intended to reflect the learning process that has been done. Furthermore, the teacher also provides suggestions so that students remain eager to learn to achieve better results.

To maintain student motivation, at the end of the lesson, the teacher expresses a speech that shows satisfaction with student learning and continues to excite students. The speech can be seen in quotation 15 .

\section{Quotation 15: \\ Teacher: "Saya senang sekali melihat kalian serius" [I am very happy to see you guys being serious] \\ Teacher: "Besok lebih semangat lagi ya!" [Tomorrow, you have to be even more excited!]}

In the speech, the teacher conveys feelings of pleasure because he sees his students study seriously. The expression of pleasure is to foster enthusiasm and student motivation. Furthermore, in his speech, the teacher encourages students to be even more excited about learning.

The teacher's speech showing appreciation and conditional statements can be seen in quotation 16.

\footnotetext{
Quotation 16:

Teacher: "Kalian tadi bersemangat dalam belajar." [You were excited in studying]

Teacher: "Makanya, hasil belajar kalian bagus." [Therefore, your learning outcomes are good]

Teacher: "Jika kalian seperti ini terus, kalian pasti bisa menjadi anak yang pandai" [If you continue
}

like this, you can become smart students]

The teacher gives appreciation for the seriousness of students in learning. He concluded that the learning outcomes achieved by students were good. To maintain student motivation in learning, the teacher makes a statement that students will become smart children if they continue to study hard.

The teacher's speech that shows evaluative speech and conditional statements can be seen in quotation 17.

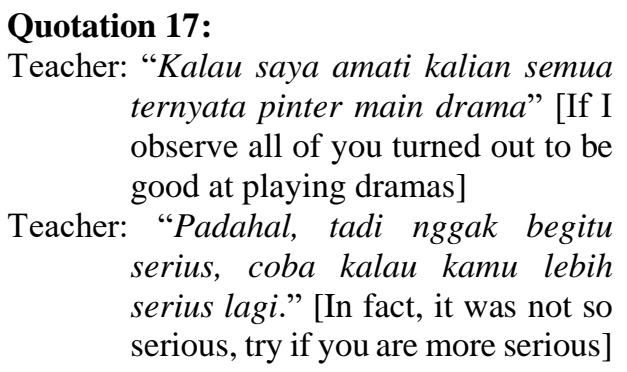
ternyata pinter main drama" [If I observe all of you turned out to be good at playing dramas]

Teacher: "Padahal, tadi nggak begitu serius, coba kalau kamu lebih serius lagi." [In fact, it was not so serious, try if you are more serious]

The teacher gives an evaluation of students' excellent learning performance. Evaluative speech is intended to maintain and increase student motivation. In the next speech, the teacher uses a paradox statement that makes students more serious in learning.

\section{Discussion}

Based on the findings described above, as the quotation $1-7$, it can be said that the varieties of teachers' speech for stimulating students' readiness in learning include (a) greeting by addressing the name of the student, (b) making small talk followed by an appeal (c) asking past lessons and assignments, (d) asking students for attention in a questioning style, (e) conveying learning objectives by checking student understanding, (f) giving suggestions in a reprimand style, and (g) advising students to focus on learning. The speech style is conveyed in a choice of words that varies according to class conditions. These findings are in line with (Lang, 2017) statement that in starting the learning class by asking questions, reviewing the experience of the previous session, reactivating prior knowledge, and providing writing exercises.

In class interactions, greeting and addressing are important speeches in starting a conversation. The speech is seen as if it is a ritual 
utterance that must be said by the teacher when entering the class to start learning (Shleykina, 2019). Greetings and addressing spoken by the teacher before learning begins seems to be an important part of classroom interaction. Students almost always respond positively to these utterances. Moreover, when the teacher greets them by mentioning the name or address of the class, the speech shows the teacher's concern for the students personally or all students. This can foster interest that motivates them to do better in class (Lieber, 2002).

In class interactions, the teacher after greeting often used small talk in conversations with students. Small talk was used by teachers to establish social interaction. The small talk is intended to direct students to be actively involved in learning. The topics discussed in the small talk are ordinary topics that do not drain a serious mind. Thus, the speech can attract students to focus their attention on classroom interaction (Garrels, 2019). Through the small talk, indirectly, students are stimulated to prepare themselves before learning begins.

At the beginning of the lesson, before starting the delivery of learning material, the teacher stimulates students with speeches that ask previous tasks, request student attention with a question, and give information with asking previous experiences. The speech was delivered by the teacher to stimulate students' enthuciasm to be actively encouraged to participate in learning (Washington University, 2009). Asking this assignment and previous experience is a strategy for teachers to encourage students to be aware of their responsibilities in learning. By asking about assignments and prior learning experiences, students are encouraged to participate in classroom interactions when learning begins.

In initiating learning, the teacher stimulates students to be motivated to study seriously. Before starting the activity of delivering learning material, the teacher always gives advice and reminds students to be responsible for their learning tasks. This speech is important stated by the teacher at the beginning of the lesson to attract the attention of students so that they do learning activities seriously. Students' awareness to learn seriously will have an impact on better classroom interactions. Positive class social interaction is an important key in developing students' cognitive, social, and language abilities (Bruce \& Hansson, 2011).

Providing advice and reminding students to be actively involved in learning is an important part of starting learning. Speech suggestions and reminders have an important meaning for students to be actively involved in class interactions. The growing willingness of students to engage in classroom interaction is a predictor in determining student success in school and later in life (Steedly et al., 2008) because through these interactions, students' social skills will develop well. Through positive classroom interactions, students naturally develop behaviors that are appropriate for social interaction with their peers.

The findings, as showed in quotation 7 13, described that the varieties of teachers' speech for stimulating students' concentration in learning process include (a) asking questions followed by reprimands, (b) asking questions followed by instructions, (c) giving addressing questions for conditioning, (d) explain the procedure followed by the warning, and (e) giving information followed by questions and satires. As these findings, we can find out that teachers use question utterances more to stimulate students' enthuciasm to actively interact in the learning process. In class interactions, the question speech is more dominant in directing students' attention. Strategies to get students' attention from the beginning of learning to the end of learning can be done through the questioning strategy (Smith, 2008). From these conditions, it can be concluded that the main approach in classroom interaction is question and answer and discussion. Through these questions, the teacher can increase the student initiation ratio and improve students' thinking in class. Besides, by giving questions, the teacher allows students to present their learning outcomes and questions in class.

The use of appropriate teachers' speech can stimulate learners in learning interaction process. This provides benefits for students to be more actively involved in learning that is reflected in the improvement of students' socialcognitive skills (Howarth, 2013). In this case, teachers are demanded to have the ability to choose the speech style that can maximize interaction in the classroom. Smooth and conducive learning interactions can improve the quality of the learning process and student learning outcomes. The conducive teacherstudent interaction has a significant relationship 
with the acquisition of student learning experiences. Through interaction, students as young people get the opportunity to develop more focused on their social interactions with adults. The teacher's approach to interacting with students can increase awareness, empathy, generosity, mutual respect, and a sincere desire to get to know students can have a unique contribution to the emergence of adaptive capacity, independence, resilience, selfconfidence, and knowledge of themselves as learners (Dunleavy \& Milton, 2009). In learning interactions, understanding the students' differences becomes the responsibility of the teacher as a driver of learning in determining teaching strategies that are relevant to the needs of students who have varied learning styles (Caraballe, 2015).

The use of various teachers' speeches in teaching and learning interactions depends on the context and classroom situation. In the classroom, the speech context covers the speech participant (teacher and student), speech situation, speech topic, speech purpose, speech tool. Speech act theory explains that the main variables that affect the performance of speech acts are the social status of the speaker and listener, social distance, age, intensity or seriousness of the speech situation, speech goals, length of time to interact, and speech location (Celce-Murcia, Brinton, \& Snow, 2014; Pfingsthorn, 2012). The use of speech acts requires knowledge of socio-cultural aspects related to speech and events (Borer, 2018).

The use of a variety of teachers' speeches in learning has the purpose of motivating students to focus more on learning materials. To encourage students to change their learning behavior is one of the goals in the learning process (Dimyati \& Mudjiono, 2013). The effort can be taken by the teacher through various speech styles, including through giving advice, explanation, assignment, reprimand, and others (Sardiman, 2012 \& Hamalik, 2013). This is done by the teacher because the enthusiasm of student learning is essentially influenced by external encouragement that comes from the influence of teachers (Redondo \& Jose, 2015).

In the interaction of communication in the classroom, the teacher applies many speech styles that aim to direct students to have learning motivation. One form of speech style is giving power to students (Hikmah et al., 2015). As a motivation, the use of teachers' speech style in learning functions to realize the realization through guidance and direction to students for the retention of learning activities through internal strength (Long et al., 2013). The growth of these internal forces will encourage students in learning so that they have an impact on increasing their knowledge (van der Meij et al., 2018). Based on the description, it can be stated that the teachers' speech style is a form of verbal domination that functions as a stimulus to move students more actively to study so that there is an increase in the cognitive and affective abilities of students in learning.

Based on the findings, as quotation 1417, it can be said that to maintain student motivation and learning enthusiasm, at the end of learning, the teacher uses a variety of speech styles. The speech style includes (a) reflecting learning experience and giving suggestions, (b) expressing satisfaction and encouraging, (c) giving appreciation and conditional statements, and (d) providing evaluation and paradoxical statement. These speech styles were the teacher's strategies in reviewing the learning experience that has been done. In these activities, the teacher gives impressions about student learning activities and explores student difficulties in learning. The teacher's findings in this reflection are useful for preparing students for the next class by providing suggestions by connecting learning experiences during the current class with future learning (Yale Center for Teaching and Learning, 2019).

The various speech style used by teachers at the end of learning illustrated that the nature of learning communication prioritizes the achievement of learning targets. In learning activities, the teacher sought to place a students' learning success as the main target of their learning. The choice of speech style was a vehicle for building effective interactions in learning that are not limited by the classroom context as a formal speech context. The teacher chose the speech style that can provide students' convenience to understand the learning material. Sorting out the types of formal speech styles and non-formal speech styles in the context of class interactions were somewhat excluded from the rules that should be applied (cf. Park, 2014). 
Teachers in interacting have to consider their speech style they choose according to the characteristics of their students. The characteristics of students play a meaningful role in achieving learning objectives and learning strategies. Therefore, considering the students' ability to the joint learning process is an important aspect in selecting the learning strategies. Student learning outcomes are directly influenced by cognitive strategies and learning processes (Ramirez-Arellano et al., 2018). Differences in individual student performance must be the basis for consideration in determining learning interaction (Ismail et al., 2018). Concerning these conditions, the choice of teachers' speech style plays an important role in determining the smooth interaction of learning.

The teachers' speech that matches the characteristics and expectations of students can build good interactions in the learning process. The good interaction between teacher and student makes the learning atmosphere comfortable. Such conditions have an impact on increasing the awareness of students to be enthusiastic in learning. Che Ahmad, Shaharim, \& Abdullah (2017) said that students' commitment and good atmosphere in learning interaction contribute significantly to the fluency and success of learning. The type of teachers' speech style that is by student conditions has a direct influence on student learning outcomes (Boyd, 2015).

Learning interactions or class interactions have important meanings, especially in language learning (Wang \& Castro, 2010). This interaction becomes a vehicle for negotiating to mean in obtaining language input. The meaningfulness of these interactions will be more optimal if students understand the teacher's speech used in classroom interactions. Therefore, the choice of the speech style that fits the abilities and desires of students becomes an important part of conducting the learning activities.

\section{REFERENCES}

Andewi, W., \& Waziana, W. (2019). An Analysis of Teacher's Speech Acts in Teaching and Learning Process. Teknosastik, 17 (1), 29-34. https://doi.org/10.33365/ts.v17i1.207.

Borer, B. (2018). Teaching and Learning Pragmatics and Speech Acts: An Instructional Pragmatics Curriculum Development Project for EFL Learners. https://digitalcommons.hamline.edu/

\section{CONCLUSION}

The teachers' speech has various types depending on the speech context underlying the speech events in the classroom interaction. The speech context includes students as speech partners, teachers who carry out speech functions, learning material as speech topics, learning interactions as speech situations. Speech events occur because of the purpose of the speech, namely improving the quality of the process and student learning outcomes. Therefore, the selection and use of teachers' speech are a strategy selected by teachers for stimulating students' motivation in learning. An understanding of the choice of appropriate speech is the responsibility of the teacher in preparing con-ducive classroom interactions. Therefore, these findings are important for teachers as a reference for preparing communication strategies that are appropriate to the characteristics of teaching materials and the needs of students in learning. The findings are also useful the next researcher as a comparative material in the development of study design.

\section{ACKNOWLEDGEMENT}

The researchers expressed their gratitude and appreciation to the Principal, the teachers (Indonesian, Mathematics, Natural Sciences, and English), and students at MTs. Islamiyah Songgon, Songgon District, Banyuwangi Regency, East Java, Indonesia, which has been prepared to be the subject of research. The researchers also expressed their gratitude to the Rector UM, Dean of Faculty of Letters, Head of Indonesian Departement for providing the opportunity for researchers to conduct this study.

cgi/viewcontent.cgi $?$ article $=1179 \&$ context $=$ hs ecp.

Boyd, M. P. (2015). Relations between Teacher Questioning and Student Talk in One Elementary ELL Classroom. Journal of Literacy Research, 47 (3), 370-404. https://doi.org/10.1177/1086 296X16632451. 
146 RETORIKA: Jurnal Bahasa, Sastra, dan Pengajarannya, Vol. 14, No. 1, February 2021, pp. 69-8

Bruce, B., \& Hansson, K. (2011). Promoting Peer Interaction. Autism Spectrum Disorders - From Genes to Environment. https://doi.org/10.57 $72 / 20034$

Buzzelli, C., \& Johnston, B. (2014). The Moral Dimensions of Teaching: Language, Power, and Culture in Classroom Interaction. London: Routledge.

Cao, Y. (2011). Investigating situational willingness to communicate within second language classrooms from an ecological perspective. System, 39 (4), 468-479. https://doi.org/10. 1016/ j.system.2011.10.016.

Caraballe, M. R. S. (2015). The relationship between students' learning styles and teachers' teaching styles to students' achievement. Asia Pacific Higher Education Research Journal (APHERJ), 2 (2). http://po.pnuresearchportal. org/ejournal/index.php/apherj/article/view/10 5.

Celce-Murcia, M., Brinton, D., \& Snow, M. A. (2014). Teaching English as a second or foreign language. National Geographic Learning: Heinle Cengage Learning.

Che Ahmad, C. N., Shaharim, S. A., \& Abdullah, M. (2017). Teacher-student interactions, learning commitment, learning environment and their relationship with student learning comfort. Journal of Turkish Science Education, 14, 5772. https://doi.org/10.12973/tused.10190a.

Dimyati, \& Mudjiono. (2013). Belajar dan Pembelajaran. Jakarta: Rineke Cipta.

Dunleavy, J., \& Milton, P. (2009). What did you do in school today? Exploring the Concept of Student Engagement and its Implications for Teaching and Learning in Canada. Canadian Education Association (CEA), May, 2009.

Fraser, B. J. (2012). Classroom Learning Environments: Retrospect, Context and Prospect. In B. J. Fraser, K. Tobin, \& C. J. McRobbie (Eds.), Second International Handbook of Science Education (pp. 1191-1239). Springer Netherlands. https://doi.org/10.1007/978-1-4020-904 1- 779.

Garrels, V. (2019). Getting good at small talk: Studentdirected learning of social conversation skills. European Journal of Special Needs Education, 34(3), 393-402. https://doi.org/10.1080/08856 257.2018.1458472.

Hamalik, O. (2013). Kurikulum dan Pembelajaran. Jakarta: PT. Bumi Aksara.

Hikmah, N., Bahari, Y., \& Imran. (2015). Peranan Guru dalam Membina Perilaku Siswa Bermasalah pada Proses Belajar Mengajar Sosiologi. Jurnal Pendidikan dan Pembelajaran, 4 (12), http://jurnal.untan.ac.id/index.php/jpdpb/articl e/view/12826.
Howarth, P. (2013). Increasing student interaction. TeachingEnglish | British Council | BBC. https://www.teachingenglish.org.uk/article/inc reasing-student-interaction.

Ismail, A. O., Mahmood, A. K., \& Abdelmaboud, A. (2018). Factors Influencing Academic Performance of Students in Blended and Traditional Domains. International Journal of Emerging Technologies in Learning (IJET), 13(02), 170 187. https://doi.org/10.3991/ijet.v13i02.8031.

Lang, J. M. (2017, October 26). Small Changes in Teaching: The First 5 Minutes of Class. The Teaching Center. https://teachingcenter.wustl. edu/2017/10/small-changes-first-5-minutes/

Lieber, C. M. (2002). Partners in learning: From conflict to collaboration in secondary class rooms. Educators for Social Responsibility.

Long, C., Ming, Z., \& Chen, L. (2013). The Study of Student Motivation on English Learning in Junior Middle School-A Case Study of No.5 Middle School in Gejiu. English Language Teaching, 6(9). https://doi.org/10.5539/elt.v6n 9p136.

Nasir, C., Yusuf, Y. Q., \& Wardana, A. (2019). A qualitative study of teacher talk in an EFL classroom interaction in Aceh Tengah, Indonesia. Indonesian Journal of Applied Linguistics, 8 (3), 525-535. https://doi.org/10.17509/ijal. v8i3.15251.

Park, M. Y. (2014). Teachers' Use Speech Style in the Korean Language Classroom. https://pdfs.semanticscholar.org/8cdf/2269a17 60d74c22ec 9c9127504cb9ded14b5.pdf.

Pfingsthorn, J. (2012). Teaching and Learning Pragmatics: Where Language and Culture Meet: Noriko Ishihara, Andrew D. Cohen, Longman Applied Linguistics, 2010, 370 pp., ISBN 978-1408204573, EUR 27,99. Journal of Pragmatics, 44 (4), 538-540. https://doi.org/ 10.1016/ j.pragma.2012.02.004.

Ramirez-Arellano, A., Acosta-Gonzaga, E., BoryReyes, J., \& Hernández-Simón, L. M. (2018). Factors affecting student learning performance: A causal model in higher blended education. Journal of Computer Assisted Learning, 34 (6), 807-815. https://doi.org/10.1111/jcal.12289.

Redondo, \& Jose. (2015). Motivation: The Road to Successful Learning. Jurnal: Teachers' Professional Development, 17 (2), 125-136. http://dx.doi.org/10.15446/profile.v17n2.505 63.

Sardiman. (2012). Interaksi dan Motivasi Belajar Mengajar. Jakarta: PT RajaGrafindo Persada.

Sharpe, T. (2008). How can teacher talk support learning? Linguistics and Education, 19, 132148. https://doi.org/10.1016/j.linged.2008.05. 001. 
Shleykina, G. (2019). The Interlanguage Pragmatics of Greetings. http://journal.wima.ac.id/index. php/BW/article/view/1848/0.

Smith, G. A. (2008, December 16). First-Day Questions for the Learner-Centered Classroom [The National Teaching \& Learning Forum]. T.I.P.S. for Faculty. https://tipsforfaculty.com/ 2008/12/16/smith-first-day-questions-for-thelearner-centered-classroom-\%ef\%bf $\%$ bc $\%$ ef\%bf\%bc/.

Steedly, K. M., Levin, M., Schwartz, A., \& Luke, S. D. (2008). Social Skills and Academic Achievement. Evidence for Education, III (II), 8. http://www.parentcenterhub.org/wp-content/ uploads/repo_items/eesocialskills.pdf.

van der Meij, H., van der Meij, J., Voerman, T., \& Duipmans, E. (2018). Supporting motivation, task performance and retention in video tutorials for software training. Educational Technology Research and Development, 66 (3), 597-614. https://doi.org/10.1007/s11423-0179560-z.

Wang, Q., \& Castro, C. D. (2010). Classroom Interaction and Language Output. English
Language Teaching, 3 https://doi.org/10.5539/elt.v3n 2p175.

(2). Washington University. (2009). Increasing Student Participation. The Teaching Center. https:// teachingcenter.wustl.edu/resources/teachingmethods/participation/increasing-studentparticipation/.

Wells, G. (1999). Dialogic inquiry: Towards a sociocultural practice and theory of education. Cambridge University Press. https://doi.org/10. 1017/CBO9780511605895.

Wicaksono, B. H. (2016). Teacher's Talk Role in Teaching Speaking. Proceedings of ISELT FBS Universitas Negeri Padang, 4 (1), 123-131. http://ejournal.unp.ac.id/index.php/selt.

Yale Center for Teaching and Learning. (2019). The Beginning and End of Class | Poorvu Center for Teaching and Learning. https://poorvucenter. yale.edu/Beginning-End-Class.

Yusuf, F. N., \& Novita, O. E. (2020). EFL teachers' perceived language proficiency and teaching effectiveness. Indonesian Journal of Applied Linguistics, 9 (3), 580-588. https://doi.org/10. 17509/ijal.v9i3.23208. 